\title{
Effects of Operating Pressure on Hydraulic Energy Nozzle Suitable for Herbicide Application
}

\author{
N. Sridhar ${ }^{1 *}$ and D. Asokan ${ }^{2}$ \\ ${ }^{1}$ Department of Farm Machinery and Power Engineering, AEC\&RI, Kumulur, \\ Trichy- 621 712, Tamil Nadu Agricultural University, India \\ ${ }^{2}$ AEC\&RI, Tamil Nadu Agricultural University, Coimbatore- 641 003, India \\ *Corresponding author
}

\begin{tabular}{|c|c|}
\hline & A B S T R A C T \\
\hline $\begin{array}{l}\text { Key w or d s } \\
\text { Operating pressure, } \\
\text { Discharge rate, } \\
\text { Width of the spray }\end{array}$ & \multirow{3}{*}{$\begin{array}{l}\text { In modern agricultural systems, chemical-based weed control is becoming difficult to } \\
\text { ignore (usage of herbicides) in weed management because of its effectiveness to } \\
\text { accomplish weed control and at the same time, increases yield largely. However, both } \\
\text { economic and ecological attention the application of herbicide should be optimum. } \\
\text { Keeping in view, the laboratory experiment was conducted and the performance of } \\
\text { selected hydraulic energy nozzle through discharge rate, uniformity coefficient, the width } \\
\text { of spray and angle of spray were measured and analyzed with a pressure range of } 20 \text { to } 50 \\
\text { psi at an interval of } 10 \text { psi.Results of laboratory investigation show that the discharge rate, } \\
\text { the width of spray, angle of spray and operating pressure viz., } 0.98 \text { lit/min, } 32.5 \mathrm{~cm}, 63.5 \\
\text { deg and } 40 \text { psi of } \mathrm{N}_{1}(0.5 \mathrm{~mm} \text { of orifice size) was found to be optimum for herbicide } \\
\text { application in a cotton field. }\end{array}$} \\
\hline Article Info & \\
\hline $\begin{array}{l}\text { Accepted: } \\
\text { 10 May } 2019 \\
\text { Available Online: } \\
\text { 10 June } 2019\end{array}$ & \\
\hline
\end{tabular}

\section{Introduction}

The yield losses due to weed competition in crop field are estimated to vary from 40 to 85\% (Shelke and Bhosle, 1990). Therefore, control of weeds is essential to reduce the yield gap between actual and potential yield. This leads to excessive pressure on agricultural land to ensure increased crop production to meet the demand of the nation. The herbicides are most commonly applied to the entire field without considering the discharge rate. This practice results in spraying just as less or herbicide on targeted areas where few or no weeds exist. Proper application of herbicides results in the overcome of environmental problems such as soil and groundwater pollution. Blumhorst et al., 1990 reports the herbicide application rates should be a function of soil properties because soils properties like organic matter content, moisture content, $\mathrm{pH}$, etc. are not uniform. Many researchers have investigated strategies to control weeds with less herbicide to reduce production cost and to protect the environment. Though most of the herbicide is applied uniformly in fields, there is strong evidence that weeds are not disturbed 
uniformly within crop field, because weeds to occur in clumps or patches (Mortensen, et.al. 2000 and Johnson, et al., 2002). Branton et al., (2005) reported spray application programs can prove difficult to maintain consistent levels of efficacy due to the inherent variability in dosage. Keeping in view the essential ofthe appropriate application of herbicide, a laboratory experiment was conducted and analysis had doneto identify the most suitable hydraulic energy nozzle for herbicide application. Thus, it would help the farmers to reduce the wastage of chemicals along with effective control of weeds in the field.

\section{Materials and Methods}

The commercially available various orifice size viz., 0.50 and $0.75 \mathrm{~mm}$ of flat fan nozzle were selected to study the spray characteristics at different pressure. The discharge rate of the selected nozzle was tested for the pressure range of 20 to $50 \mathrm{psi}$ at an interval of10 psi. The discharge rate was measured by collecting the discharge fluid $(\mathrm{v})$ for a unit time at one minute $(\mathrm{t})$ in a measuring jar and it was calculated as

$q=\frac{V}{t}$ litre/minute

\section{Measurement of the spray distribution pattern}

The standard spray patternator was used for the study to measure spray width, spray angle and spray distribution pattern of selected hydraulic energy flat fan nozzles. Each nozzle was mounted at a height of $30 \mathrm{~cm}$ above the patternator in such a way that the axis of spray was at a right angle to the horizontal. At the pressure of $20,30,40$ and $50 \mathrm{psi}$, the sprayed liquid was collected in the glass tubes for one minute and the volume of collected liquid from each channel of patternator was noted. The width of spray was calculated by the width of coverage of uniform distribution each nozzle on patternator. For the same distribution, the height of nozzle placement was noted and the spray angle was calculated as follows

$\theta=2 \tan ^{-1}\left(\frac{W}{2 H}\right)$

Where,

$\theta=$ spray angle, deg

$\mathrm{W}=$ width of spray, $\mathrm{cm}$

$\mathrm{H}=$ height of the nozzle from patternator, $\mathrm{cm}$

\section{Uniformity coefficient of spray distribution}

The uniformity coefficient of hydraulic energy nozzles was calculated at different operating pressure by using the volume of water collected in each tube from the patternator. The uniformity coefficient of selected nozzles and coefficient of variation were calculated at different operating pressures by using the standard equation as follows (Herbst and Wolf, 2001).

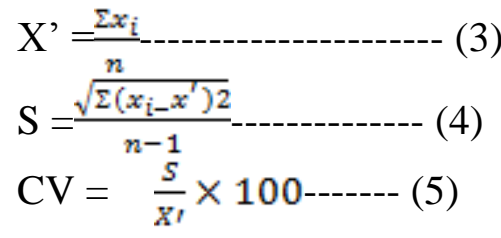

Where,

C.V. $=$ The coefficients of variation percentage, $\%$

$\mathrm{Xi}=$ Height of liquid in the tube, $\mathrm{cm}$

$\mathrm{N}=$ Number of patternator columns

\section{Results and Discussion}

\section{Effect of pressure on discharge rate}

The discharge rate for the selected nozzles was directly proportional to pressure. Irrespective of pressure $\mathrm{N}_{2}$ nozzle $(0.75$ orifice size ) recorded maximum discharge rate of1.19 lit/min at 50 psi followed byN ${ }_{1}$ nozzle $(0.5 \mathrm{~mm}$ orifice size) $1.01 \mathrm{lit} / \mathrm{min}$ at 50 
psi as shown in Figure 1. The selected nozzles discharge rate gradually increases with increasing pressure, which was in close agreement with the results reported by Senthil Kumar (2007) and Singh (2006).

\section{Effect of pressure on spray angle and spray width}

The spray patternator was used to calculate the width of the spray and spray angle of the selected hydraulic energy nozzle. The width of spray for $\mathrm{N}_{1}$ nozzle $(0.5 \mathrm{~mm}$ orifice size) and $\mathrm{N}_{2}$ nozzle $(0.75 \mathrm{~mm}$ orifice size $)$ was increased from $27.5 \mathrm{~cm}$ to $32.5 \mathrm{~cm}$, and 30 $\mathrm{cm}$ to $35 \mathrm{~cm}$ with an increase in working pressure from $20 \mathrm{psi}$ to $40 \mathrm{psi}$ respectively as shown in Figure 2. The maximum width of spray was observed at $30 \mathrm{~cm}$ height from spray patternator.

The spray angle was increased 54.89 to 69.91 deg and 59.03 to 71.57 deg respectively for $\mathrm{N}_{1}$ nozzles $(0.5 \mathrm{~mm}$ orifice size $)$ and $\mathrm{N}_{2}$ nozzle
(0.75 $\mathrm{mm}$ orifice size) with an increase in working pressure from 20 psi to 40 psi as shown in Figure 3.

\section{Effect of pressure on uniformity coefficient}

From Figure 4, it was observed that the spray distribution is improved by increasing nozzle orifice size and operating pressure. The coefficient of variation in the spray distribution of $\mathrm{N}_{1}$ nozzle ( $0.5 \mathrm{~mm}$ orifice size) was $26.09,25.87,24.77$ and 25.78 percent and $\mathrm{N} 2$ nozzle $(0.75 \mathrm{~mm}$ orifice size nozzle) was $23.08,20.87,18.69$ and 21.05 percent at the pressures of 20, 30, 40 and 50 Psi respectively. The coefficient of variation in spray distribution was lowest for $0.75 \mathrm{~mm}$ orifice size nozzle $\left(\mathrm{N}_{2}\right)$ as compared to other nozzles. The $\mathrm{N}_{2}$ nozzle gave best results at a pressure of 40 psi with least coefficient of variation of 18.69 percent which was in close agreement with the results reported by Sehsah et al., (2009) and Syed Imran et al., (2018).

Table.1 The correlation coefficient of discharge rate with influencing parameters

\begin{tabular}{|l|c|c|c|}
\hline \multicolumn{1}{|c|}{ Parameter } & $\begin{array}{c}\text { Coefficients for the } \\
\text { discharge rate of } \\
\text { the spray nozzle }\end{array}$ & $\begin{array}{c}\text { Coefficients for } \\
\text { the width of the } \\
\text { spray nozzle }\end{array}$ & $\begin{array}{c}\text { Coefficients for } \\
\text { the angle of spray } \\
\text { nozzle }\end{array}$ \\
\hline Intercept & 0.22 & 13.21 & 31.55 \\
\hline Operating pressure $\mathbf{( P ) , ~ p s i ~}$ & 0.0061 & 0.28 & 0.46 \\
\hline Nozzle orifice size (N), mm & 1.018 & 14.04 & 23.24 \\
\hline R Square & 0.97 & 0.95 & 0.94 \\
\hline
\end{tabular}

Fig.1 Effect of operating pressure on discharge rate of various orifice size nozzle

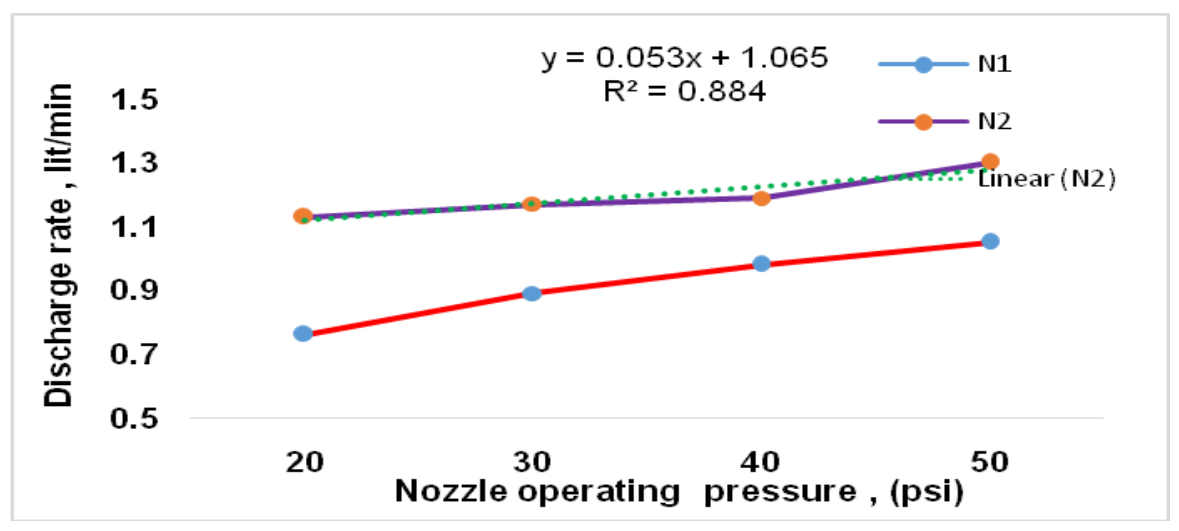


Fig.2 Effect of operating pressure on the width of a spray of various orifice size nozzle

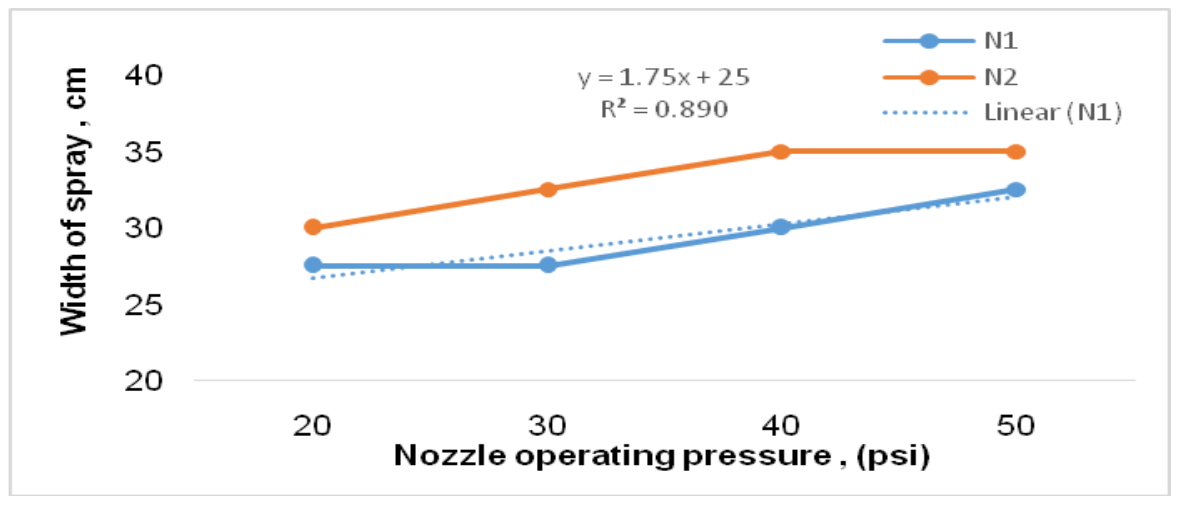

Fig.3 Effect of operating pressure on the angle of a spray of various orifice size nozzle

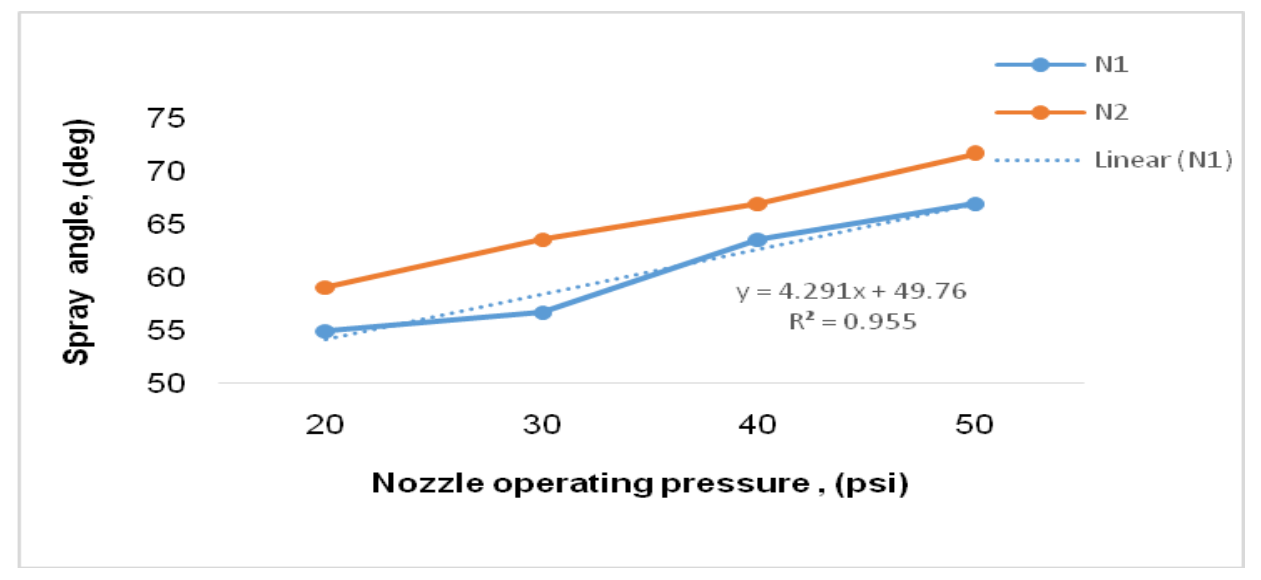

Fig.4 Effect of the nozzle pressures on the coefficient of variation percentage

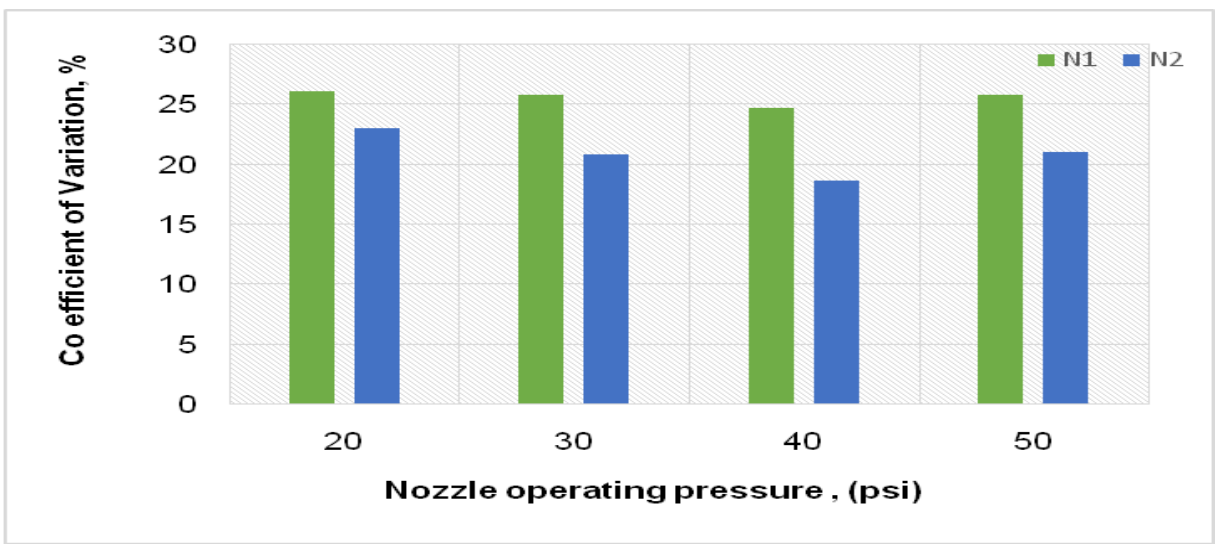

\section{Multiple linear regression analysis}

A multiple linear regression analysis was carried out with combining independent variables during the laboratory experiment and the results were presented in Table 1. From Table 1 a mathematical model correlating the independent variables namely operating pressure $(\mathrm{P})$ and nozzle orifice size (N) was arrived as in the following equation 
Discharge rate $(Q)$, lit $/$ min $=0.22+0.0061 \mathrm{P}+1.018 \mathrm{~N}$ ..(6)

Width of spray nozzle (W), $\mathrm{cm}=13.21+0.28 \mathrm{P}+14.048 \mathrm{~N}$ ..(7)

Angle of spray $(\theta), \mathrm{deg}=31.55+0.46 \mathrm{P}+23.24 \mathrm{~N}$

From the above equation, it was found that the dependent parameter discharge rate $(\mathrm{Q})$, the width of spray and angle of spray has a positive relation with operating pressure and nozzle orifice size. The analysis of variance $\left(\mathrm{R}^{2}\right)$ was found out as $97,0.95$ and 0.94 percent respectively.

In conclusion, the discharge rate, the width of spray and spray angle of selected hydraulic energy nozzles, which are proportional to the increase in operating pressure. Results show that the discharge rate, the width of spray, angle of spray and operating pressure viz., $0.98 \mathrm{lit} / \mathrm{min}, 32.5 \mathrm{~cm}, 63.5 \mathrm{deg}$ and $40 \mathrm{psi}$ of $\mathrm{N}_{1}(0.5 \mathrm{~mm}$ of orifice size) was found to be optimum for herbicide application in a cotton field. The minimum value(18.69 percent) of the coefficient of variation represents good uniformity distribution, which was obtained for $\mathrm{N}_{2}$ nozzle followed by $\mathrm{N}_{1}$ nozzle.

\section{References}

Blumhorst, M.R., J. B. Weber, and L. R. Swain. 1990. Efficacy of selected herbicides as influenced by soil properties. Weed Technol.4: 279-283.

Branton, S. L., W. B. Roush, B. D. Lott, J. D. Evans, W. A. Dozier III, S. D. Collier, S. M. D. Pearson, B. L. Pearson, and G. T.
Pharr. 2005. A self-propelled, constant-speed spray vaccinator for commercial layer chickens. Avian Dis. 49(1): 147-151.

Herbst, A. and P. Wolf (2001). Spray deposit distribution from agricultural boom sprayers in dynamic conditions. ASAE Meeting Paper 01-1054.

Johnson, E. N. and B. Frick. 2002. Inter-row cultivation - effective weed control in field pea,Pages 113-134 in G. P. Lafond, J. T. McConnell, L. Gutek, and B. Sim, eds. SPOKE Program Research Reports. AgriFood Innovation Fund.

Mortensen, D. A., Bastiaans, L., and Sattin, M. 2000. The role of ecology in the development of weed management systems: an outlook. Weed Res. 40: 49-62

Sehsah E and S Kleisinger (2009) Study of some parameters affecting spray Distribution uniformity pattern. Misr J. Ag. Eng., January 2009.

Senthilkumar. T., and V.J.F. Kumar 2007.Evaluation of hydraulic energy nozzles suitable for orchard spraying. Agricultural Mechanization in Asia, Afric, and Latin America. 38(2), 13-17.

Shelke J.H., Bhosle R.H., 1990. Determination of critical periods of crop-weed competition in rainfed cotton. Journal of Maharashtra Agricultural Universities 15 (2): 257-258.

Singh S K, S. Singh, V. Sharda, and N Singh. 2006. Performance of different nozzles for tractor mounted sprayers. J Res Punjab Agric Univ., 43(1): 44-49.

Syed Imran $\mathrm{S}$ and A. Surendrakumar 2018.valuation of Hydraulic Energy Nozzle Suitable for Low-Velocity Air-Assisted Sprayer. International Journal of Current Microbiology and Applied Sciences ISSN: 2319-7706 Volume 7 Number 01 (2018).

\section{How to cite this article:}

Sridhar, N. and Asokan, D. 2019. Effects of Operating Pressure on Hydraulic Energy Nozzle Suitable for Herbicide Application. Int.J.Curr.Microbiol.App.Sci. 8(06): 1101-1105. doi: https://doi.org/10.20546/ijcmas.2019.806.136 